\title{
Protein Kinase C Regulates the Interaction between a GABA Transporter and Syntaxin 1A
}

\author{
Matthew L. Beckman, ${ }^{1,2}$ Eve M. Bernstein, ${ }^{1}$ and Michael W. Quick ${ }^{1}$ \\ ${ }^{1}$ Department of Neurobiology and ${ }^{2}$ Medical Scientist Training Program, University of Alabama at Birmingham, \\ Birmingham, Alabama 35294-0021
}

\begin{abstract}
Syntaxin 1A inhibits GABA uptake of an endogenous GABA transporter in neuronal cultures from rat hippocampus and in reconstitution systems expressing the cloned rat brain GABA transporter GAT1. Evidence of interactions between syntaxin $1 A$ and GAT1 comes from three experimental approaches: botulinum toxin cleavage of syntaxin $1 \mathrm{~A}$, syntaxin $1 \mathrm{~A}$ antisense treatments, and coimmunoprecipitation of a complex containing GAT1 and syntaxin 1A. Protein kinase $C$ (PKC), shown previously to modulate GABA transporter function, exerts its
\end{abstract}

Neurotransmitter transporters are integral membrane proteins, expressed at or near the synapse on neurons and glia, that function by coupling the uptake of neurotransmitter to the movement of cotransported ions down their electrochemical gradients. The influences of transporters on synaptic signaling are diverse. Pharmacological blockade of specific transporters can prolong and/or increase the amplitude of postsynaptic responses mediated via GABA (Isaacson et al., 1993), NMDA (Sarantis et al., 1993; Barbour et al., 1994), and AMPA (Hestrin et al., 1990; Tong and Jahr, 1994) receptors. At "slow" synapses, these transportermediated signaling effects could be attributable to transmitter transport directly (see Lester et al., 1994); at "fast" synapses, the role of the transporter is likely attributable to its ability to bind extracellular neurotransmitter rapidly (Diamond and Jahr, 1997). Additionally, transporters may directly alter membrane excitability by inducing "channel-like" ion fluxes in the presence of substrate and by permitting substrate-independent "leak" currents (for review, see Sonders and Amara, 1996; Beckman and Quick, 1998).

Factors that regulate neurotransmitter transporter function will necessarily influence these processes, and such factors include a variety of intracellular second messengers (for review, see Clark and Amara, 1993; Beckman and Quick, 1998). In particular, modulation of uptake by protein kinase $\mathrm{C}$ (PKC) has been described for most transporters (for review, see Beckman and Quick, 1998); stimulation of PKC exerts its effects by changing the number of functional transporters expressed on the plasma mem-

\footnotetext{
Received Feb. 19, 1998; revised May 26, 1998; accepted May 28, 1998.

These experiments were supported by a United States Public Health Service Grant (DA-10509), the Epilepsy Foundation of America, and the W. M. Keck Foundation (931360). We thank Nick Brecha for providing the anti-GAT1 antibodies, Zucheng Ye for instructions on preparing primary astrocytes and for providing initial cultures, Kevin Kirk for providing PC12 cells and syntaxin and Munc18 cDNAs and antibodies, and Smith-Kline Beecham for a sample of SKF89976A.

Correspondence should be addressed to Dr. Michael W. Quick, Department of Neurobiology, CIRC 446, 1719 Sixth Avenue South, Birmingham, AL 35294-0021. Copyright (C) 1998 Society for Neuroscience $0270-6474 / 98 / 186103-10 \$ 05.00 / 0$
}

modulatory effects by regulating the availability of syntaxin $1 \mathrm{~A}$ to interact with the transporter, and a transporter mutant that fails to interact with syntaxin $1 \mathrm{~A}$ is not regulated by PKC. These results suggest a new target for regulation by syntaxin $1 \mathrm{~A}$ and a novel mechanism for controlling the machinery involved in both neurotransmitter release and reuptake.

Key words: neurotransmitter uptake; synaptic vesicle proteins; second messengers; protein regulation; protein-protein interactions; GABA transport brane (Corey et al., 1994b; Qian et al., 1997; Quick et al., 1997; Davis et al., 1998).

Syntaxin $1 \mathrm{~A}$ is a plasma membrane protein involved both in trafficking and vesicle docking and/or fusion (Bennett et al., 1992, 1993) and in the direct regulation of $\mathrm{Ca}^{2+}$ channels (Bezprozvanny et al., 1995) and cystic fibrosis transmembrane regulator (CFTR) $\mathrm{Cl}^{-}$channels (Naren et al., 1997). Data from coexpression studies in oocytes suggest a functional interaction between syntaxin 1A and the cloned rat brain GABA transporter GAT1 (Quick et al., 1997). However, the biological relevance of PKC and syntaxin $1 \mathrm{~A}$ in transporter regulation and the mechanisms underlying the functional modulation by these molecules have not been elucidated.

In the present report, we show that syntaxin $1 \mathrm{~A}$ and $\mathrm{PKC}$ functionally regulate GABA transport in cells that endogenously express these proteins. In mammalian cell reconstitution systems, coimmunoprecipitation experiments demonstrate an association between GAT1 and syntaxin 1A that can be regulated by PKC. Syntaxin $1 \mathrm{~A}$ is necessary but not sufficient to confer PKCmediated transporter regulation, and reconstitution experiments suggest that PKC modulation likely occurs via interactions of the syntaxin 1A-GAT1 complex with other syntaxin 1A-binding partners that are substrates for PKC modification (e.g., Munc18). Such functional regulation is lacking in a mutant GAT1 protein that does not interact with syntaxin $1 \mathrm{~A}$. These data (1) suggest that a network of protein-protein interactions is responsible for the functional regulation of GABA transport, (2) describe one mechanism for PKC modulation of transporter function, and (3) accumulate additional evidence to suggest that syntaxin $1 \mathrm{~A}$ is a general regulator of excitability protein activity.

\section{MATERIALS AND METHODS}

Cell culture. Primary hippocampal cultures were prepared from postnatal day $0-3$ rats by mincing tissue in $\alpha$-Minimal Essential Medium ( $\alpha$-MEM) supplemented with cysteine, glucose, and $100 \mathrm{U}$ of papain (Sigma, St. Louis, MO, or Worthington, Freehold, NJ). Tissue was incubated for 20 min at $37^{\circ} \mathrm{C}$, followed by gentle trituration, dilution, and plating onto poly-L-lysine-coated glass coverslips. To obtain pure neuronal cultures, 
we treated mixed cultures for $48 \mathrm{hr}$ with $10 \mu \mathrm{M}$ cytosine arabinoside (Sigma); treatment was initiated $24 \mathrm{hr}$ after plating. Astrocyte cultures were prepared as described (Ye and Sontheimer, 1996). Cells were plated onto untreated 24-well plates and maintained in Earle's MEM supplemented with $10 \%$ FBS.

Pheochromocytoma (PC12) cells were maintained in RPMI 1640 supplemented with $10 \%$ horse serum, $5 \%$ FBS, L-glutamine, and penicillin-streptomycin. 1F9 cells [Chinese hamster ovary cells stably expressing GAT1 (Corey et al., 1994a)] were maintained in $\alpha$-MEM supplemented with 5\% FBS, L-glutamine, and penicillin-streptomycin. Transient transfections were performed using Lipofectamine (Life Technologies, Gaithersburg, MD) in Optimem I (Life Technologies). The lipid-DNA mix was incubated with the cells for $5 \mathrm{hr}$; cells were then rinsed and refed with complete media. Stable transformants were obtained by selection in $500 \mathrm{ng} / \mathrm{ml} \mathrm{G} 418$ (Life Technologies). PC12 cell transfections were supplemented with $50 \mathrm{ng} / \mathrm{ml} 7 \mathrm{~S}$ mouse nerve growth factor (Alomone Labs).

$\left[{ }^{3} H\right] G A B A$ uptake assays. Cells were rinsed twice in $1 \times \mathrm{HBSS}$ and allowed to equilibrate for $10 \mathrm{~min}$ in the final wash. Buffer was then exchanged with control HBSS or drug-containing HBSS; preincubation times were $10-30 \mathrm{~min} .\left[{ }^{3} \mathrm{H}\right] \mathrm{GABA}$ was added to initiate the assay. The final $\left[{ }^{3} \mathrm{H}\right] \mathrm{GABA}$ concentration was $30 \mathrm{~nm}$, and assay times were $10-60$ min. The assay was terminated by rapidly rinsing the cells three times with $1 \times$ HBSS, followed by solubilization in $300 \mu \mathrm{l}$ of $0.001-0.005 \%$ SDS at $37^{\circ} \mathrm{C}$ for $2 \mathrm{hr}$. Aliquots were used for scintillation counting and to determine protein concentrations. Statistical analyses of the uptake data were performed using SPSS. Two-sample comparisons were made using $t$ tests; multiple comparisons were made using one-way ANOVAs, followed by Tukey's honest significant difference post hoc test.

Antisense experiments. The rat syntaxin sense and antisense (Bennett et al., 1992) oligonucleotides have been described (Quick et al., 1997). Briefly, they corresponded to bases -1 to 18 (sense strand, 5' GATGAAGGATCGGACTCAG-3'), a region divergent in sequence from other syntaxin isoforms based on the published sequence. For antisense inhibition experiments, $1 \mathrm{ml}$ of the oligonucleotides $(10 \mu \mathrm{M}$, final concentration) was incubated with cells in $1 \%$ serum media with Lipofectamine for $6 \mathrm{hr} ; 1 \mathrm{ml}$ of $20 \%$ serum media was then added to the cells without removing the oligonucleotides.

Mutant GAT1 constructs. Truncation mutants were created using the PCR. The N-terminal truncation mutant $(\mathrm{GAT} 1 \Delta \mathrm{N})$ was produced using the following primer set: (upstream) 5' -TTTCCAAAGCTTTGGATGGCGACTGTAGTCAAGGTGCAGAAG-3'; and (downstream) 5'TCTGTGAAAGCCCCCAAGGG-3'. This resulted in the production of a GAT1 construct lacking bases 10-91, corresponding to amino acids 4-30. PCR products were cloned into pCR 2.1 (Invitrogen, San Diego, $\mathrm{CA})$, screened by restriction analysis, and subcloned into $\mathrm{pRC} / \mathrm{cytomeg-}$ alovirus (Invitrogen) at the HindIII and ApaI sites. A GAT1 consensus phosphorylation site mutant (T236A) was made using Altered Sites I (Promega, Madison, WI). GAT1 T236A was subcloned into pcDNA3 for transfection studies. The GAT $1 \Delta 4 \mathrm{~L}$ mutant was made using the Transformer site-directed mutagenesis kit (Clontech, Cambridge, UK) as described (Quick et al., 1997). Leucines at positions 83, 90, 97, and 104 were changed to alanines. All mutants were confirmed by sequencing.

Immunoprecipitations. Immunoprecipitation was performed by lysing cells in radio-immunoprecipitation assay buffer as described (Naren et al., 1997). The lysate was treated with protein $\mathrm{G}$-agarose and $0.8 \mathrm{mg}$ of syntaxin antibody. The product was precipitated, resuspended, and run on a $6 \%$ acrylamide gel. Protein was transferred to a polyvinylidene difluoride membrane (Pierce, Rockford, IL) by electroblotting. Western blotting of PC12 cells, 1F9 cells, and oocytes was performed using anti-GAT1 antibodies as described (Corey et al., 1994b) and was visualized using ECL reagents (Amersham, Arlington Heights, IL).

\section{RESULTS}

Much data demonstrating transporter regulation by $\mathrm{PKC}$ and by components of the vesicle docking and fusion apparatus come from experiments involving heterologous expression systems. To establish the biological relevance of these molecules in regulating endogenous transporters in brain, we examined modulation of GABA transport in both neuronal and astrocyte cultures from rat hippocampus. The data from neuronal cultures are shown in Figure $1 A$. Pretreatment of neurons with phorbol 12-myristate 13-acetate (PMA), a phorbol ester that activates PKC, decreased
GABA uptake to $46 \pm 4 \%$ of control values. A non-PKCactivating phorbol ester, $4 \alpha$-phorbol 12,13-didecanoate ( $4 \alpha \mathrm{PDD})$, had no effect on transport $(96 \pm 6 \%)$. The PKC effects on GABA uptake in these neurons are likely mediated via the rat brain GABA transporter encoded by GAT1 (Guastella et al., 1990) because SKF89976A, a potent inhibitor of GAT1-mediated transport (Larsson et al., 1988), essentially abolished uptake.

To examine the role of components of the docking and fusion apparatus on endogenous GABA transport in hippocampal neurons, we used clostridial toxins to inactivate particular synaptic vesicle and plasma membrane-trafficking proteins. These results are shown in Figure $1 A$. Pretreatment of neurons with botulinum toxin $\mathrm{C} 1$ (BONT/C1), which specifically cleaves syntaxin $1 \mathrm{~A}$ near its membrane anchor (Blasi et al., 1993), caused an $\sim 75 \%$ increase in GABA uptake $(176 \pm 14 \%)$; this syntaxin-mediated change in uptake could be completely blocked by SKF89976A. This upregulation in GABA transport did not occur in cells treated with botulinum toxin B (BONT/B), which specifically inactivates the vesicle-associated protein synaptobrevin (108 \pm $14 \%$ ). In addition, the inhibition of GABA uptake that occurred with PMA was eliminated in neurons also treated with BONT/C1 $(163 \pm 15 \%)$. The PMA-induced inhibition of uptake $(44 \pm 6 \%)$ remained in cultures cotreated with BONT/B.

Modulation of GABA transport by PMA and BONT/C1 does not occur in pure astrocyte cultures also prepared from rat hippocampus. These data are shown in Figure $1 B$. Under the same treatment conditions used for the pure neuronal cultures, PMA $(92 \pm 11 \%), \mathrm{BONT} / \mathrm{C} 1(105 \pm 6 \%)$, or both compounds together $(88 \pm 11 \%)$ failed to alter GABA uptake significantly when compared with that in untreated control cultures. The lack of effect with BONT/C1 is consistent with the lack of syntaxin $1 \mathrm{~A}$ in these astrocyte cultures, as assessed by immunoblot using a syntaxin 1A-specific antibody (data not shown). Treatment of astrocytes with SKF89976A did inhibit uptake significantly (57 \pm $6 \%$ ), suggesting that the GAT1 transporter does mediate some GABA uptake in these astrocytes. However, other GABA transporters may also be involved in hippocampal astrocyte uptake because nipecotic acid, a less-selective GABA transporter substrate with higher affinity than GABA, decreased GABA uptake to $8 \%$ of control values. These data from hippocampal cultures demonstrate that endogenous GABA transport, specifically in neurons, is regulated by $\mathrm{PKC}$ and $\mathrm{BONT} / \mathrm{C} 1$ and that the $\mathrm{PKC}$ induced inhibition is eliminated by $\mathrm{BONT} / \mathrm{C} 1$.

The modulatory actions of $\mathrm{PKC}$ and $\mathrm{BONT} / \mathrm{C} 1$ on endogenous GABA transport prompted us to ask whether these molecules also regulate uptake of other transporters. These results, for endogenous glutamate transport in both neuronal and astrocyte cultures, are shown in Figure $1 C$. In neuronal cultures, application of PMA increased glutamate uptake $(167 \pm 12 \%)$; this increase is consistent with previous reports (Casado et al., 1993; Davis et al., 1998). As was seen with GABA transport, application of BONT/C1 increased glutamate uptake $(158 \pm 13 \%)$. Interestingly, coapplication of PMA and BONT/C1 caused a significant increase in uptake $(212 \pm 14 \%)$ compared with that in cultures treated with PMA alone. In astrocyte cultures, PMA caused an increase in glutamate transport $(159 \pm 9 \%)$; this PMA-induced increase in astroctye cultures is consistent with previous data (Casado et al., 1991). BONT/C1 had no effect on glutamate transport and failed to influence the PMA-induced increase. These data show (1) that BONT/C1 regulates both GABA and glutamate transport in neurons, (2) that BONT/C1 influences the PKC-mediated modulation of both GABA and glutamate uptake, 
A

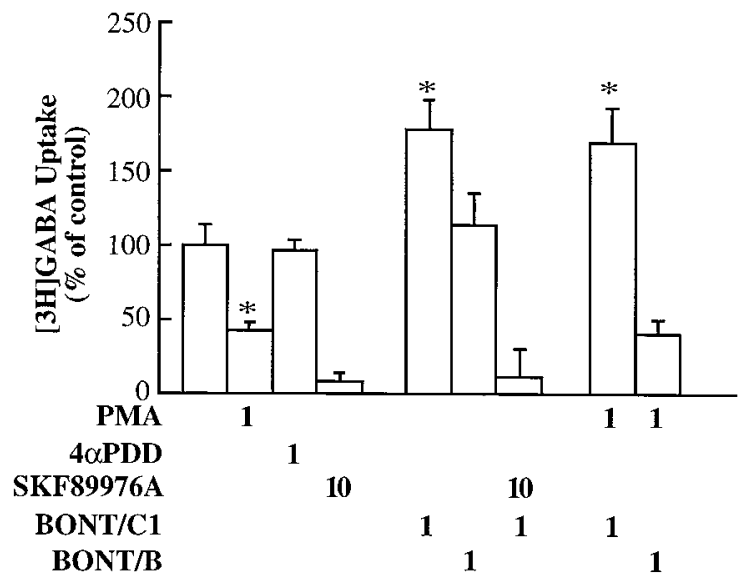

B

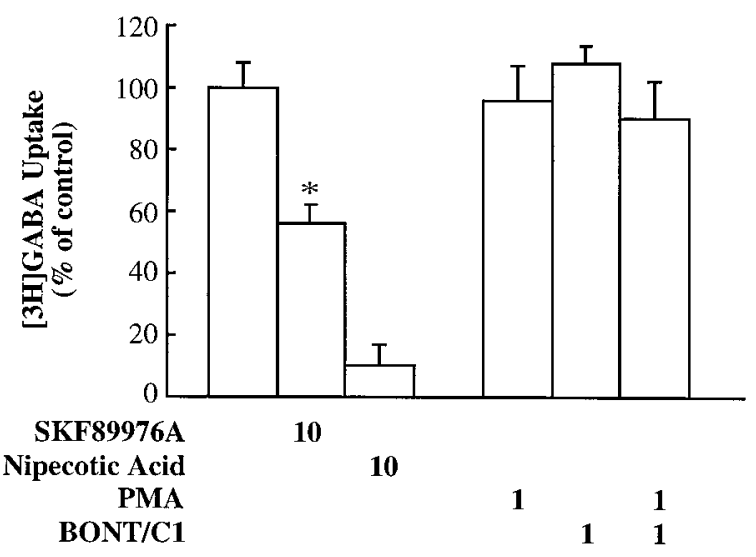

C

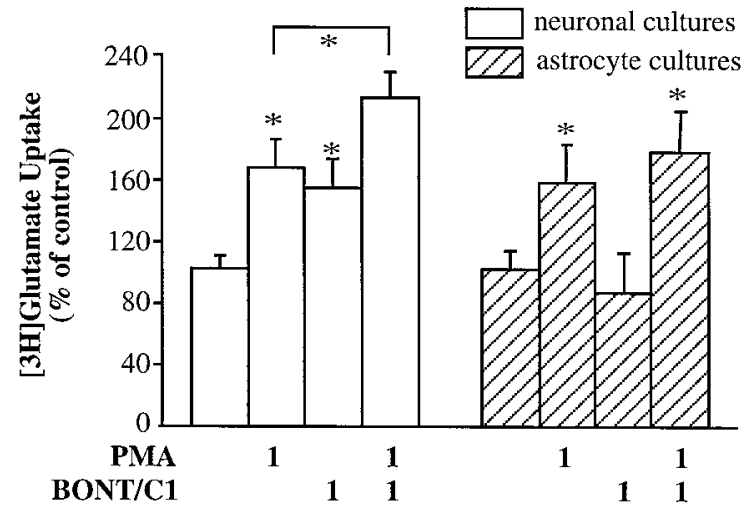

Figure 1. GABA uptake in hippocampal neurons is regulated by botulinum toxin $\mathrm{C} 1$ and protein kinase C. $A$, Modulation of GABA uptake in neuronal cultures. Drug and toxin concentrations (in $\mu \mathrm{M}$ ) are shown below the graph. Pretreatment (30 min) of cultures with PMA, but not $4 \alpha \mathrm{PDD}$, decreased $\left[{ }^{3} \mathrm{H}\right] \mathrm{GABA}$ uptake. Uptake was blocked in all conditions tested by the GAT1 antagonist SKF89976A. Pretreatment (30 min) of cultures with BONT/C1, but not BONT/B, increased $\left[{ }^{3} \mathrm{H}\right] \mathrm{GABA}$ uptake and prevented the PMA-mediated decrease. Data are from four separate experiments, three wells per condition per experiment. GABA uptake under control conditions ranged from 716 to $1211 \mathrm{fmol} / \mathrm{min}$ per $\mathrm{mg}$ of protein. $B$, Modulation of GABA uptake in astrocyte cultures. Astrocyte GABA uptake is not modulated by PKC or botulinum toxin. Treatments are described in $A$. Data are from three experiments, at least four wells per condition per experiment. GABA uptake under control conditions ranged from 116 to $323 \mathrm{fmol} / \mathrm{min}$ per $\mathrm{mg}$ of protein. $C$, Modulation of glutamate uptake in neuronal and astrocyte cultures. Treatments are described in $A$. Data are from three experiments, eight wells per condition per experiment. Mean neuronal glutamate uptake under control conditions was $897 \mathrm{fmol} / \mathrm{min}$ per $\mathrm{mg}$ of protein; mean astrocyte glutamate and (3) that there is a BONT/C1-independent regulation of glutamate uptake by $\mathrm{PKC}$, suggesting multiple pathways for PKCmediated regulation of transport. These conclusions will be more fully developed in the Discussion.

\section{PKC and botulinum toxin regulation of transport can be recapitulated in PC12 cells expressing GAT1}

Given the data from hippocampal neurons suggesting that regulation of transport was mediated via GAT1, we sought an expression system that would mimic the endogenous phenomenology and that would allow us to make a detailed characterization of the mechanisms underlying this regulation. We expressed GAT1 in rat $\mathrm{PC} 12$ cells. The data in Figure $2 A$ show that this system faithfully reproduces the $\mathrm{PKC}$ and $\mathrm{BONT} / \mathrm{C} 1$ regulation seen in neurons. PMA treatment resulted in a twofold reduction in GABA uptake that did not occur with $4 \alpha$ PDD (data not shown). Pretreatment with 1-(5-isoquinolinylsulfonyl)-homopiperazine dihydrochloride (HA-1077), an intracellular $\mathrm{Ca}^{2+}$ antagonist (Takayasu et al., 1986), caused a significant increase in GABA uptake $(138 \pm 11 \%)$ and reversed the PMA-induced inhibition. Calphostin C, a specific PKC inhibitor (Kobayashi et al., 1989), also reversed the PMA inhibition. As seen in neurons, BONT/C1 caused a significant increase in GABA uptake $(162 \pm 9 \%)$ and prevented the PMA-induced inhibition. BONT/B had no effect on GABA transport (data not shown). Two control experiments verified that the regulation is occurring via the expressed GAT1 transporter; (1) wild-type PC12 cells show GABA uptake that is only $1 \%$ of GAT1-transfected PC12 cells (data not shown), and (2) SKF89976A essentially eliminates uptake.

Changes in uptake induced by PMA and BONT/C1 could be produced, in general, either by altering the turnover rate of individual transporters or by altering the number of functional transporters. By analogy with receptor-binding experiments, data obtained from saturation curve analysis are often used to distinguish between these two possibilities; changes in the maximum velocity of transport $\left(\mathrm{V}_{\max }\right)$ are indicative of changes in the number of transporter binding sites, and changes in affinity $\left(K_{\mathrm{m}}\right)$ are indicative of changes in the function of individual transporters. Saturation analysis and Eadie-Hofstee transformations were performed on PC12-GAT1 cells assayed in the presence or absence of PMA (Fig. 2B) and in the presence or absence of BONT/C1 (Fig. 2C). The results demonstrate changes in $\mathrm{V}_{\max }$ that reflect the magnitude of the regulation by these molecules. No changes in $K_{\mathrm{m}}$ were seen with either treatment. These data are consistent with a mechanism in which these molecules alter the number of functional transporters, as suggested previously (Corey et al., 1994b; Qian et al., 1997; Quick et al., 1997), and further support the idea that the BONT/C1 and PMA effects are mediated via a similar pathway.

\section{Syntaxin 1A interacts with, and functionally regulates, GAT1}

Syntaxin $1 \mathrm{~A}$ is a plasma membrane protein that regulates neurosecretion (Bennett et al., 1993); it also directly interacts with, and regulates, $\mathrm{Ca}^{2+}$ channels (Sheng et al., 1994; Bezprozvanny et al., 1995) and CFTR (Naren et al., 1997). The data showing BONT/C1 upregulation of GABA transport in both neurons and

uptake under control conditions was $2714 \mathrm{fmol} / \mathrm{min}$ per $\mathrm{mg}$ of protein Experimental conditions that resulted in a significant change $(p<0.05)$ from control values or between the indicated groups are denoted by an asterisk. 
A

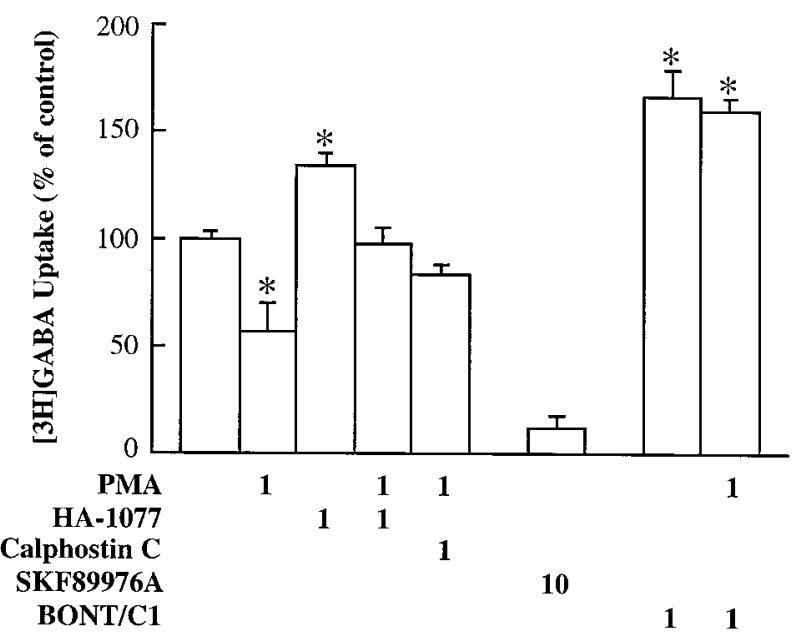

Figure 2. PC12 cells expressing GAT1 are regulated by botulinum toxin $\mathrm{C} 1$ and protein kinase C. $A$, GAT1 regulation in PC12 cells mimics endogenous GABA transporter regulation. Cells were treated as described in Figure $1 \mathrm{~A}$ and the Results. Data are from two to six different experiments, at least three wells per condition per experiment. GABA uptake under control conditions ranged from 2744 to $8297 \mathrm{fmol} / \mathrm{min}$ per $\mathrm{mg}$ of protein. Experimental conditions that resulted in a significant change $(p<0.05)$ from control values are denoted by an asterisk. $B$, PMA decreases transport $\mathrm{V}_{\max }$ (open circles) compared with that in untreated controls ( filled circles). Top, Saturation analysis was performed at six different GABA concentrations for cells in the presence or absence of $1 \mu \mathrm{M}$ PMA. Bottom, EadieHofstee transformations of these data are shown. $C, \mathrm{BONT} / \mathrm{C} 1$ increases transport $\mathrm{V}_{\max }$ (open circles) compared with that in untreated cells (filled circles). Experiments are described in $B$. BONT/C1 concentration was $1 \mu \mathrm{M}$. Saturation experiments were performed twice; data shown are from one experiment.
B
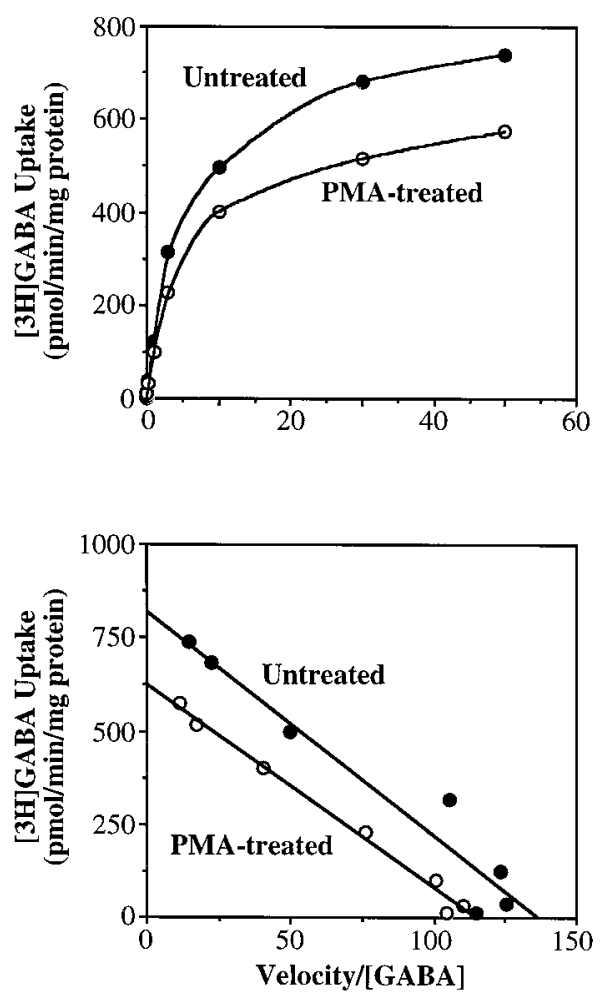

$\mathbf{C}$
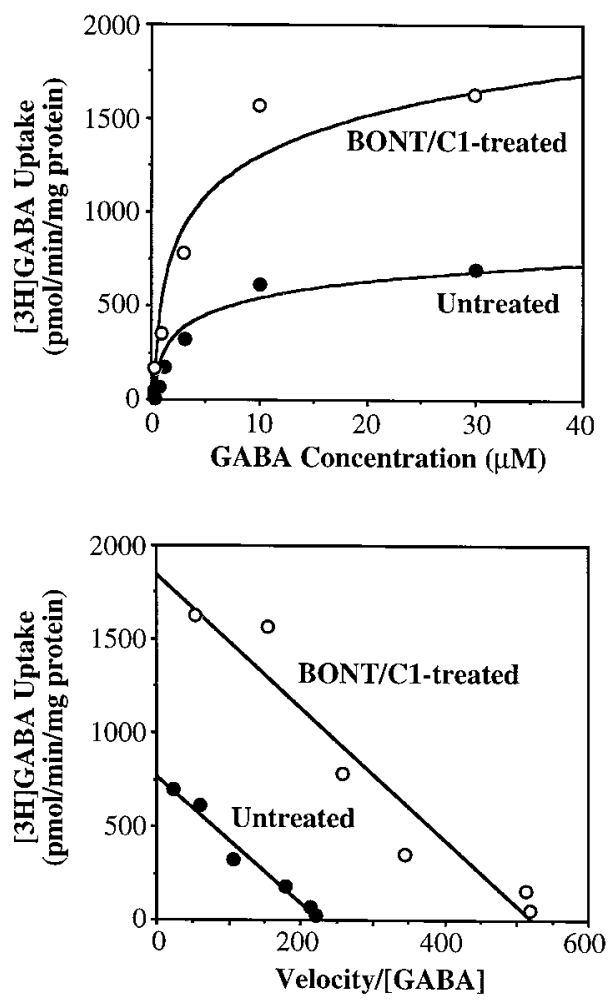

PC12 cells expressing GAT1 suggested that syntaxin 1A may be similarly regulating GAT1 function. We provide two additional experimental approaches that support this hypothesis.

Antisense oligonucleotides directed against syntaxin 1A inhibit syntaxin 1A expression and upregulate GABA uptake. These results are shown in Figure 3. PC12 cells stably expressing GAT1 were incubated for $48 \mathrm{hr}$ in media containing sense or antisense oligonucleotides comprising the first 18 bases of the syntaxin $1 \mathrm{~A}$ coding sequence. Compared with either untreated control cultures or cultures incubated with sense strand oligonucleotides, cultures treated with antisense strand oligonucleotides showed significantly increased levels of GABA uptake $(155 \pm 12 \%)$ (Fig. $3 A$ ). Incubation of cells with a 19 base scrambled oligonucleotide did not alter GABA uptake (data not shown). Additionally, BONT/C1-mediated increases in GABA uptake were less in cultures treated with antisense oligonucleotides than in cultures treated with sense oligonucleotides. This result is consistent with the inhibition of syntaxin $1 \mathrm{~A}$ protein synthesis by the antisense oligonucleotides. To examine the time course of this effect, we incubated PC12-GAT1 cells with syntaxin 1A oligonucleotides for 0,24 , and $48 \mathrm{hr}$. The magnitude of the increase in GABA uptake was dependent on the length of time that PC12-GAT1 cells were incubated with syntaxin 1A oligonucleotides (Fig. 3B, graph). Parallel PC12-GAT1 samples at each time point were assessed by Western blot using anti-syntaxin 1A or anti-GAT1 transporter antibodies. The magnitude of the increase in uptake was inversely correlated with the amount of syntaxin 1A protein present (Fig. 3B, left blot). There was no change in GABA transporter protein levels at any time point (Fig. 3B, right blot).

A specific association between the GAT1 transporter and syn- 
A
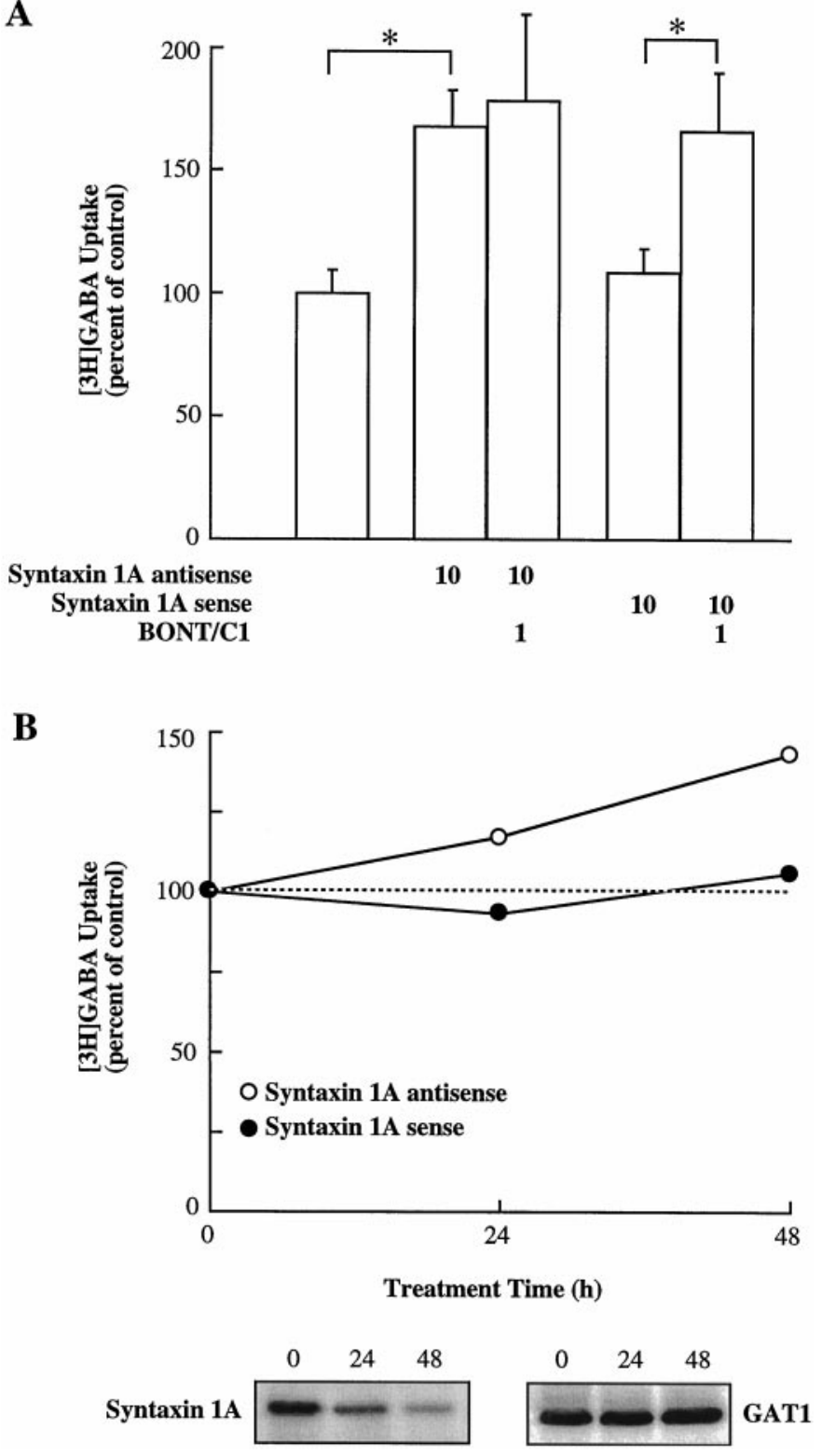

Figure 3. Inhibiting syntaxin 1A expression upregulates GAT1 transport in PC12 cells. $A$, Syntaxin 1A antisense oligonucleotide treatment of PC12 cells causes an increase in GABA uptake. PC12 cells expressing GAT1 were incubated for $48 \mathrm{hr}$ with $10 \mu \mathrm{M}$ antisense or sense oligonucleotides as described in Materials and Methods. Some cells were treated $30 \mathrm{~min}$ before assay with $1 \mu \mathrm{M} \mathrm{BONT/C1}$. Data are from three experiments, six wells per condition per experiment. GABA uptake under control conditions ranged from 1865 to $2767 \mathrm{fmol} / \mathrm{min}$ per $\mathrm{mg}$ of protein. Experimental conditions that resulted in a significant difference $(p<0.05)$ between the two identified groups are denoted by an asterisk. $B$, The increase in GABA uptake correlates with a decrease in syntaxin 1A expression. PC12 cells were treated as described in $A$. $\left[{ }^{3} \mathrm{H}\right] \mathrm{GABA}$ uptake experiments were performed 0,24 , or $48 \mathrm{hr}$ after oligonucleotide application. Parallel samples were harvested for Western blot analysis and probed with antibodies to either syntaxin 1A (lower left blot) or GAT1 (lower right blot).

taxin $1 \mathrm{~A}$ is evident from the data shown in Figure 4. PC12-GAT1 cell lysates were immunoprecipitated using a syntaxin $1 \mathrm{~A}$ antibody. The presence of GAT1 protein in these immunoprecipitates was assessed by Western blot using GAT1-specific antibodies generated against the $\mathrm{C}$-terminal portion of the GAT1 protein as described previously (Minelli et al., 1995). Two different GAT1
A

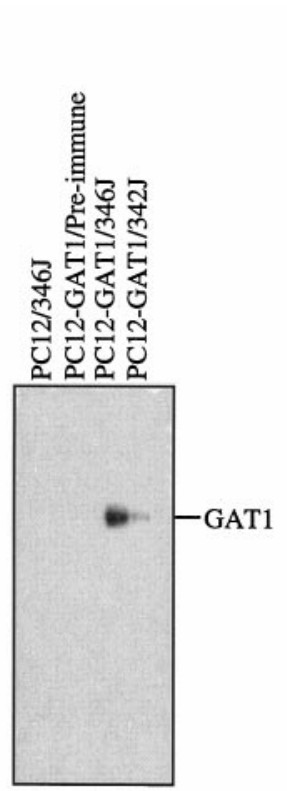

B

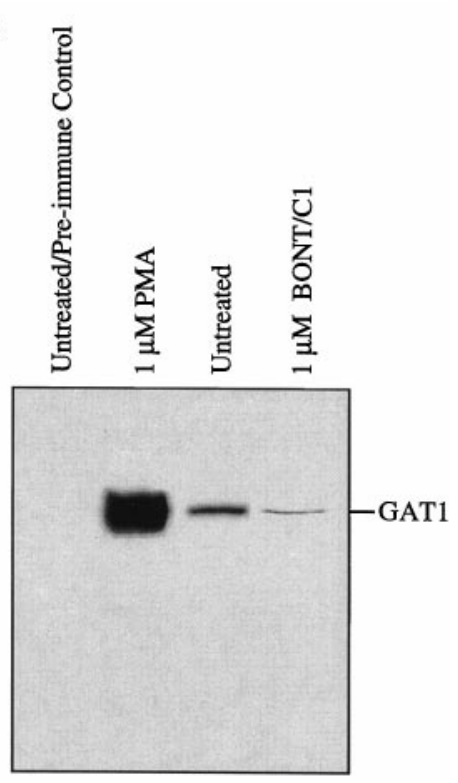

Figure 4. Syntaxin 1A interacts with GAT1. $A$, Syntaxin 1A and GAT1 coimmunoprecipitate. PC12 cells expressing GAT1 were precipitated with anti-syntaxin 1A antibody, and GAT1 was visualized by Western blot using two different anti-GAT1 antibodies (346J and 342J). Wild-type PC12 cells probed with antibody $346 \mathrm{~J}$ and PC12-GAT1 cells probed with preimmune serum served as controls. Antibody $346 \mathrm{~J}$ was used in all further immunoblot experiments. $B$, Protein kinase $\mathrm{C}$ regulates the interaction between syntaxin 1A and GAT1. Cells were pretreated for 30 min with PMA or BONT/C1 before precipitation with the syntaxin $1 \mathrm{~A}$ antibody. $C$, The interaction between syntaxin 1A and GAT1 is specific. 1F9 cells were cotransfected with either syntaxin 1A (Syn 1A) or syntaxin 3 (Syn 3). Forty-eight hours later, $\left[{ }^{3} \mathrm{H}\right] \mathrm{GABA}$ uptake assays were performed. Data are from three experiments, six wells per condition per experiment. GABA uptake under control conditions ranged from 365 to $923 \mathrm{fmol} / \mathrm{min}$ per $\mathrm{mg}$ of protein. Experimental conditions that resulted in a significant change $(p<0.05)$ from control values are denoted by an asterisk. Top blot, Immunoprecipitation with either syntaxin 1A or syntaxin 3 antibodies was performed on parallel samples and Western blotted with the GAT1 antibody. Bottom blots, Specificity of each antibody for syntaxin $1 \mathrm{~A}$ and syntaxin 3 was determined by immunoblot of membranes prepared from oocytes expressing either syntaxin subtype. For all immunoblot experiments, equal amounts of protein were added in each lane.

antibodies, 346J and 342J, were immunoreactive in PC12-GAT1 immunoprecipitates (Fig. 4A). Immunoprecipitates from PC12GAT1 cells subsequently blotted with preimmune serum and immunoprecipitates from wild-type PC12 cells subsequently blotted with the $346 \mathrm{~J}$ antibody were nonreactive. 
Table 1. Reconstitution of syntaxin inhibition and PKC sensitivity in $1 F 9$ cells.

Types of Acute Treatment

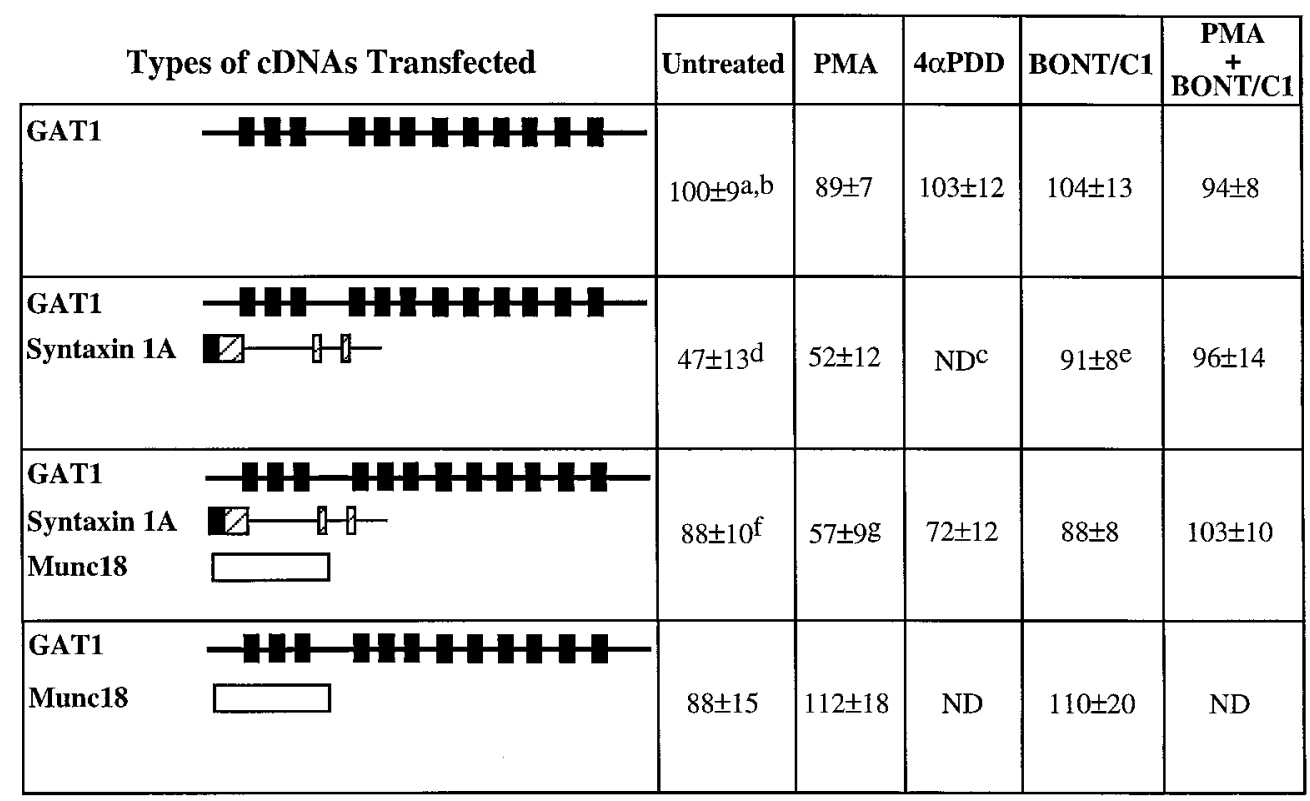

${ }^{\text {a}}$ Data are from 2-4 experiments, 4-6 wells/experiment.

${ }^{\mathrm{b}}$ All data in this Table are expressed relative to this control condition. Control uptake values range from 514 to $1160 \mathrm{fmol} / \mathrm{min} / \mathrm{mg} \mathrm{protein}$.

${ }^{\mathrm{c}}$ Experiment not performed.

${ }^{\mathrm{d}} p<0.05$ compared to untreated GAT1.

${ }^{\mathrm{e}} p<0.05$ compared to untreated GAT1/Syntaxin $1 \mathrm{~A}$.

${ }^{\mathrm{f}} p<0.05$ compared to untreated GAT1/Syntaxin 1A.

${ }^{\mathrm{g}} p<0.05$ compared to PMA-treated GAT1 and compared to untreated GAT1/Syntaxin 1A/Munc 18.

As shown above in both hippocampal neurons and PC12-GAT1 cells, BONT/C1 prevented PKC-mediated inhibition of GABA uptake. These data suggested that PKC and syntaxin $1 \mathrm{~A}$ might be mediating their regulatory actions via a common pathway. To test this hypothesis, we treated PC12-GAT1 cells with PMA for 30 min before immunoprecipitation with the syntaxin $1 \mathrm{~A}$ antibody. The results of this experiment are shown in Figure $4 B$. Compared with no treatment of PC12-GAT1 cells, PMA treatment resulted in an increase in the amount of GAT1 protein in complex with syntaxin 1A, as assessed by subsequent Western blotting with antibody 346J. Pretreatment of PC12-GAT1 cells with BONT/C1 greatly reduced the amount of GAT1 in complex with syntaxin 1A. These data show that PKC regulates the interaction between syntaxin 1A and GAT1 and that this interaction requires intact, membrane-anchored syntaxin $1 \mathrm{~A}$.

To examine the specificity of the association between the GAT1 transporter and syntaxin 1A, we coexpressed either syntaxin $1 \mathrm{~A}$ or syntaxin 3 with the stably expressing GAT1 cell line 1F9 (Corey et al., 1994a). Syntaxin 3 shares 64\% identity with syntaxin $1 \mathrm{~A}$ at the amino acid level and is highly expressed in spleen and lung but not in brain (Bennett et al., 1993). Results of this experiment are shown in Figure $4 C$. GABA uptake assays show that the inhibition in uptake is specific for syntaxin $1 \mathrm{~A}(58 \pm$ $6 \%)$. Syntaxin 3 had no effect on GABA uptake $(96 \pm 10 \%)$. The top blot in Figure $4 C$ shows that the functional inhibition of the transporter by syntaxin 1A was associated with an ability to coimmunoprecipitate these two molecules. Syntaxin 3 did not immunoprecipitate a complex containing the transporter, even though protein levels of syntaxin $1 \mathrm{~A}$ and syntaxin 3 were comparable, as assessed by Western blot (data not shown).
To support the hypothesis that syntaxin $1 \mathrm{~A}$ specifically and functionally associates with GAT1, several additional control experiments were performed. First, potential cross-reactivity for the syntaxin $1 \mathrm{~A}$ and syntaxin 3 antibodies was evaluated by injecting Xenopus oocytes with cRNA encoding syntaxin 1A, 3, or 4 , and by subjecting the oocytes to immunoblot analysis. The bottom two blots in Figure $4 C$ show that the antibodies are subtype-specific. Second, to eliminate the possibility that the syntaxin 3 antibody was nonfunctional in immunoprecipitation experiments, we used GAT1 to precipitate the complex and then probed the precipitate with the syntaxin antibodies. Results similar to those shown in Figure $4 C$ were obtained (data not shown).

\section{Reconstitution of PKC-mediated regulation of GAT1}

Although PKC regulation of transporters is well described (see Beckman and Quick, 1998) and direct phosphorylation of some transporters has been shown, the mechanism(s) underlying PKCmediated regulation has not been elucidated. The ability of PKC to regulate the interaction of syntaxin 1A and GAT1 in immunoprecipitation experiments led us to examine whether syntaxin 1A was necessary or sufficient for PKC-mediated inhibition of transport. To address this issue, we first expressed GAT1 in 1F9 cells and performed GABA uptake assays during a variety of acute drug treatments. These data are shown in the top row of Table 1. In 1F9 cells expressing GAT1 alone, treatment with PMA, BONT/C1, or both failed to modulate GABA uptake.

We next examined regulation of GABA transport in 1F9 cells expressing GAT1 and syntaxin 1A (Table 1, second row) and compared these results with 1F9 cells expressing GAT1 alone. In untreated GAT1- and syntaxin 1A-expressing cells, GABA trans- 
port was reduced approximately twofold. BONT/C1 reversed this inhibition. However, PMA failed to regulate the syntaxin 1A inhibition of uptake. Taken together with the PMA data from hippocampal neurons and PC12 cells, these data suggest that syntaxin 1A is not sufficient to confer PKC regulation of GAT1.

In neurons and PC12 cells, syntaxin 1A interacts with several proteins involved in neurosecretion, including $\mathrm{Ca}^{2+}$ channels, synaptosomal associated protein-25, and Munc18 (Hata et al., 1993; Söllner et al., 1993; Pevsner et al., 1994; Sheng et al., 1994). In epithelial cells, a complex containing CFTR, syntaxin 1A, and Munc18 interacts to control CFTR-mediated $\mathrm{Cl}^{-}$secretion (Naren et al., 1997). Importantly, Munc18 is a substrate for PKC phosphorylation, and in vitro phosphorylation of Munc18 prevents its association with syntaxin 1A (Fujita et al., 1996). Therefore, we expressed GAT1, syntaxin 1A, and Munc18 in 1F9 cells to test the hypothesis that a network of interactions involving these proteins would confer PKC regulation on the transporter. These results are shown in the third row of Table 1. Expression of Munc18 reversed the inhibition of GABA uptake mediated by syntaxin 1A coexpression. More importantly, this reversal was inhibited by PMA treatment, suggesting that PMA can regulate the interaction between syntaxin $1 \mathrm{~A}$ and GAT1 via effects on high-affinity syntaxin 1A-binding partners that are substrates for PKC modification. As in neurons and PC12-GAT1 cells, $\mathrm{BONT} / \mathrm{C} 1$ treatment eliminates PMA-mediated regulation of the transporter. Munc18 was unable to regulate GAT1 in the absence of syntaxin 1A (Table 1, bottom row).

\section{A GAT1 mutant that does not interact with syntaxin 1A is not regulated by $\mathrm{PKC}$}

The 1F9 cell reconstitution experiments and the PC12 coimmunoprecipitation experiments suggested that PKC regulates the availability of syntaxin to interact with, and functionally inhibit, the transporter. To test this hypothesis, we generated a number of GABA transporter mutants and examined their ability to both (1) interact with syntaxin $1 \mathrm{~A}$ and (2) be modulated by PKC. We reasoned that mutants in which syntaxin $1 \mathrm{~A}$ and GAT1 could not be coimmunoprecipitated would be insensitive to modulation by PKC. Data from two of these mutants are shown in Figure 5. GAT $1 \Delta \mathrm{N}$ is a truncation mutant that removed part of the predicted cytoplasmic N-terminal tail of the transporter; GAT1 $\Delta 4 \mathrm{~L}$ is a mutant that modifies a leucine heptad repeat sequence by changing leucines to alanines [amino acids 83, 90, 97, and 104 (Quick et al., 1997)]. PC12 cells expressing wild-type transporters or the two transporter mutants were assayed for GABA uptake both in the presence and absence of PMA (Fig. 5A). PMA inhibited wild-type and GAT1 $\Delta \mathrm{N}$; however, the GAT1 $\Delta 4 \mathrm{~L}$ mutant was unaffected by PMA treatment. These functional results correlated with coimmunoprecipitation experiments (Fig. $5 A$, blot) showing that the GAT1 $\Delta 4 \mathrm{~L}$ mutant did not associate with syntaxin $1 \mathrm{~A}$. The fact that syntaxin $1 \mathrm{~A}$ did not coimmunoprecipitate with the GAT1 $\Delta 4 \mathrm{~L}$ mutant also argues against the likelihood that syntaxin 1A nonspecifically associates with GAT1. To confirm further that PKC and syntaxin 1A exert their effects via a common pathway, we treated PC12 cells expressing GAT1 4 L with PMA and BONT/C1. Compared with the results in PC12 cells expressing wild-type GAT1, GABA uptake in the GAT1 $\Delta 4 \mathrm{~L}$ mutant was not altered by either PMA or BONT/C1 (Fig. 5B). These data are consistent with the hypothesis that the transporter must associate with syntaxin $1 \mathrm{~A}$ to be regulated by PKC and potentially identify one region of GAT1 that is important for functional modulation by syntaxin $1 \mathrm{~A}$.
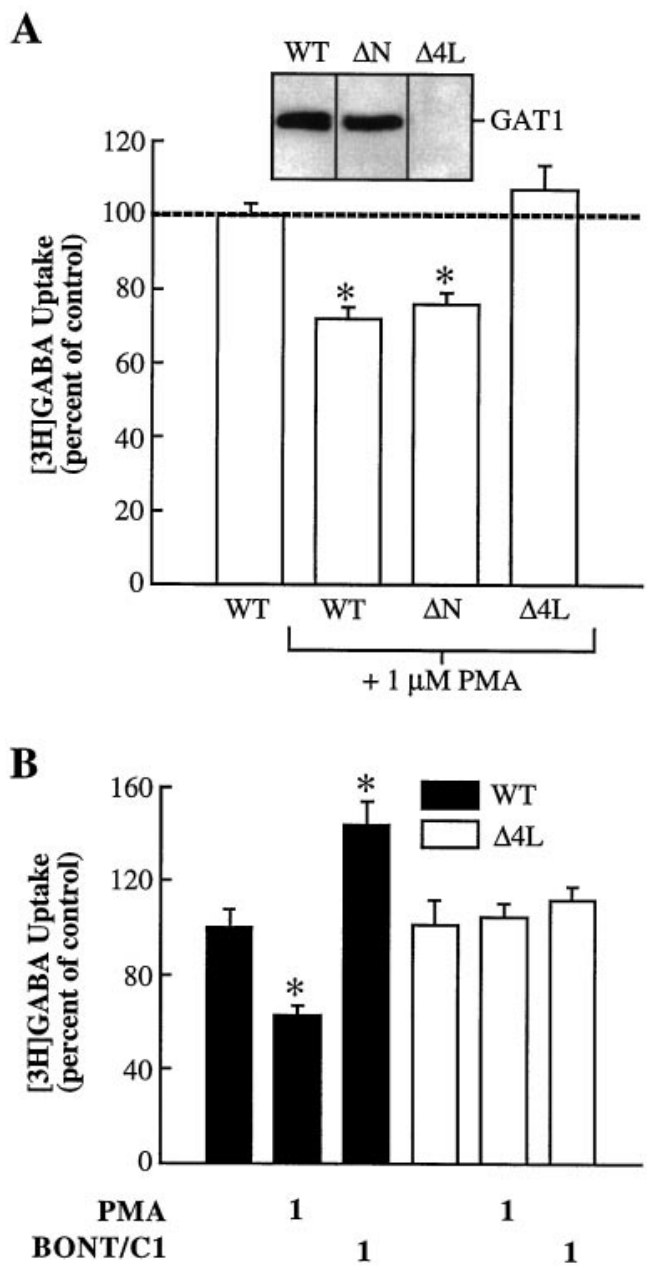

Figure 5. GAT1 mutants that fail to interact with syntaxin 1A are not regulated by PKC. $A$, A GAT1 mutant lacking a leucine heptad repeat sequence does not interact with syntaxin 1A. Mutant GABA transporters lacking the cytoplasmic $\mathrm{N}$-terminal tail $(\Delta N)$ or a leucine heptad repeat $(\Delta 4 L)$ were expressed in PC12 cells. $\left[{ }^{3} \mathrm{H}\right] \mathrm{GABA}$ uptake assays were performed on cultures treated with PMA and were compared with untreated cultures. Only the control result for the wild-type (WT) condition is shown. The mean control GABA uptake values for each condition (in $\mathrm{fmol} / \mathrm{min}$ per $\mathrm{mg}$ of protein) were as follows: wild-type, $1337 ; \Delta N, 2697$; and $\Delta 4 L, 1657$. In parallel cultures, the $\Delta 4 L$ mutant could not be immunoprecipitated by a syntaxin $1 \mathrm{~A}$ antibody $($ blot $)$. $B$, The GAT1 $\Delta 4 \mathrm{~L}$ mutant is insensitive to regulation by $\mathrm{PKC}$ or $\mathrm{BONT} / \mathrm{C} 1$. Data are from two experiments, six wells per condition per experiment. The mean control GABA uptake values for each condition (in $\mathrm{fmol} / \mathrm{min}$ per $\mathrm{mg}$ of protein) were as follows: wild-type, 1115 ; and $\Delta 4 L, 1712$. Experimental conditions that resulted in a significant change $(p<0.05)$ from control values are denoted by an asterisk.

\section{DISCUSSION}

The data from the present experiments are consistent with the model of GABA transporter regulation shown in Figure 6. The principal findings are the following: (1) GABA transport in cells that endogenously express a GABA transporter and syntaxin $1 \mathrm{~A}$ can be regulated by PKC. (2) Syntaxin 1A associates with GAT1. This result is revealed via coimmunoprecipitation of a complex containing these two proteins. (3) Syntaxin 1A inhibits GAT1 transporter function. This result is supported by four lines of evidence. Botulinum toxin cleavage of syntaxin 1A upregulates transport, antisense oligonucleotide inactivation of syntaxin $1 \mathrm{~A}$ upregulates GABA transport, coexpression of syntaxin $1 \mathrm{~A}$ and 


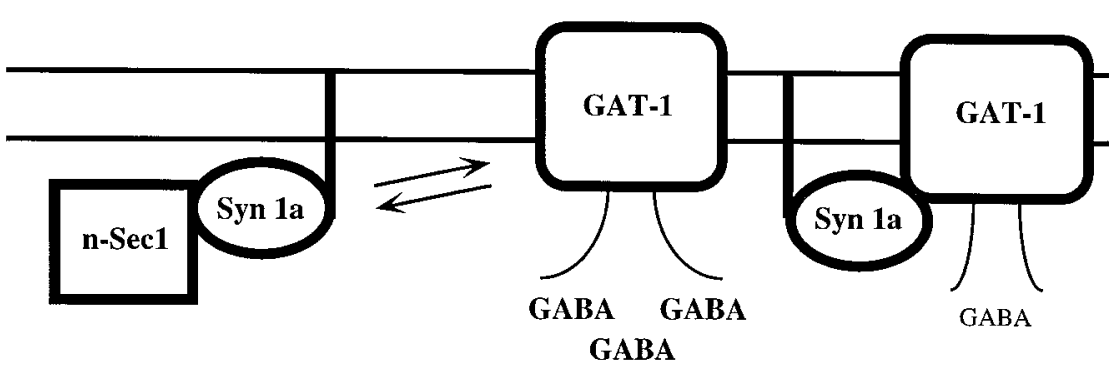

Figure 6. A model for the regulation of GAT1 by syntaxin $1 \mathrm{~A}$ and protein kinase $\mathrm{C}$. In the absence of PKC, syntaxin $1 \mathrm{~A}$ can bind to many partners including GAT1. Phosphorylation of these binding partners, e.g., Munc18 or n-Sec1, results in a greater number of syntaxin 1A and GAT1 interactions.

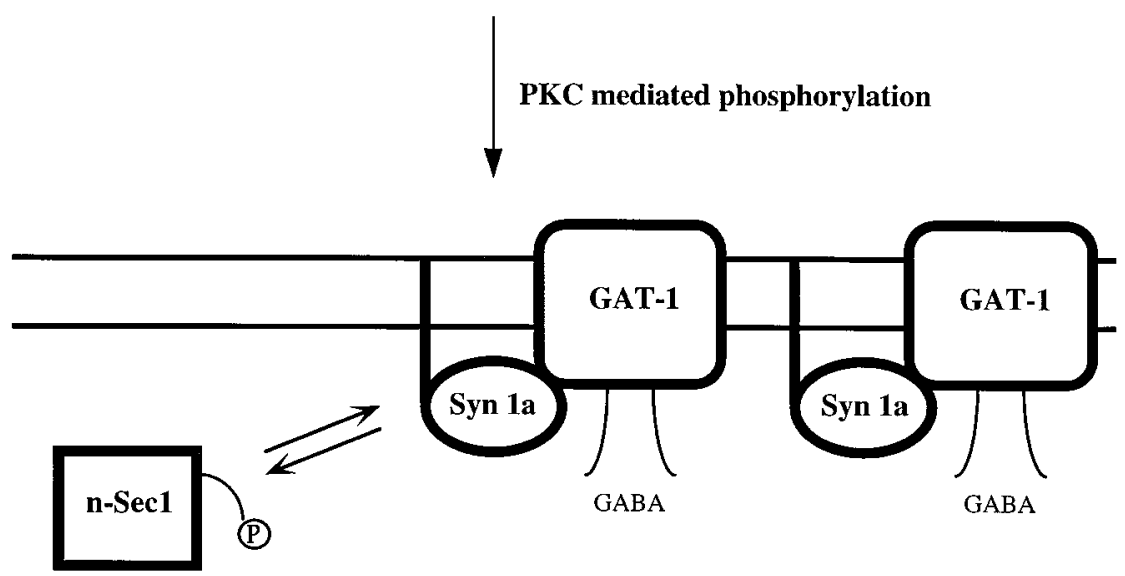

GAT1 in reconstitution experiments downregulates GABA transport, and a GAT1 transporter mutant that fails to interact with syntaxin $1 \mathrm{~A}$ is not regulated. (4) PKC, via a network of protein interactions, inhibits GABA uptake by regulating the availability of syntaxin 1A to interact with the transporter. This result is supported by four lines of evidence. PKC inhibition of GABA uptake is eliminated in cells treated with botulinum toxin; more syntaxin $1 \mathrm{~A}$ is found associated with GAT1 in PKC-treated immunoprecipitates; reconstitution of PKC inhibition of GAT1 requires both syntaxin $1 \mathrm{~A}$ and Munc18, a high-affinity syntaxin 1A-binding partner that is a substrate for PKC phosphorylation; and a GAT1 transporter mutant that fails to interact with syntaxin $1 \mathrm{~A}$ is not regulated by PKC.

The twofold modulation of GABA transport by syntaxin $1 \mathrm{~A}$ and PKC places constraints on the likely physiological role of transporter regulation in synaptic signaling. Transporter turnover rates are slow (Mager et al., 1993; Sarantis et al., 1993), and twofold changes in transmitter uptake are probably insufficient to affect synaptic events, even at slow synapses (see Lester et al., 1994). However, in addition to uptake of transmitter, transporters exhibit both nonstoichiometric, substrate-dependent ionic fluxes and substrate-independent leak currents (see Sonders and Amara, 1996; Beckman and Quick, 1998), both of which will be affected by transporter modulation. In addition, because transporter modulation is caused by changes in the number of functional transporters (Corey et al., 1994b; Qian et al., 1997; Quick et al., 1997; Davis et al., 1998), modulation by PKC and syntaxin 1A will alter the number of diffusion sinks available for transmitter sequestration. If the number of transporters at or near the synapse is comparable with the number of transmitter molecules released, then such changes in the number of transmitter binding sites will contribute significantly to the magnitude and time course of the synaptic signal (Diamond and Jahr, 1997).

The evidence of a role for syntaxin 1A in regulating the GAT1 transporter is consistent with the evolving concept of syntaxin $1 \mathrm{~A}$ as a general regulator of excitability protein function. Although originally characterized as a component of the machinery involved in the trafficking, docking, and fusion of small synaptic vesicles at the plasma membrane (Bennett et al., 1992; Söllner et al., 1993), syntaxin 1A has more recently been shown to confer "reluctant" gating to voltage-sensitive calcium channels (Bezprozvanny et al., 1995) and to inhibit cAMP-activated CFTR chloride channels (Naren et al., 1997). The GABA transporter represents the first member of a third class of excitability proteins functionally inhibited by syntaxin 1A. It is likely that other members of the $\mathrm{Na}^{+}$- and $\mathrm{Cl}^{-}$-dependent transporter family are similarly regulated by syntaxin $1 \mathrm{~A}$; members of this family share a high degree (at least 40\%) of amino acid identity, and preliminary studies from our laboratory using the rat serotonin transporter show a functional inhibition by syntaxin $1 \mathrm{~A}$. The evidence that endogenous glutamate transport in neurons can be modulated by BONT/C1 reinforces the likelihood that such a mechanism is a common feature of neurotransmitter transporter regulation.

For calcium channels and CFTR, the interaction with syntaxin $1 \mathrm{~A}$ occurs via direct protein-protein interactions. Calcium channels that are regulated by syntaxin 1A have a "synprint," a conserved region of amino acids that directly interact with synaptic proteins (Sheng et al., 1994; Mochida et al., 1996). For CFTR, the N-terminal cytoplasmic tail is necessary for syntaxin 1A binding; the $\mathrm{H} 3$ domain of syntaxin 1A, a coiled-coil domain located adjacent to the transmembrane anchor (Kee et al., 1995), is necessary and sufficient to bind CFTR (A. Naren, M. Quick, J. Collawn, D. Nelson, and K. Kirk, unpublished observations). Whether syntaxin 1A and GAT1 interact directly and what are the sites of this potential interaction remain to be determined. The evidence that a transporter mutant lacking a leucine heptad repeat motif cannot be coimmunoprecipitated with syntaxin $1 \mathrm{~A}$ and that leucine heptad motifs are sites for protein-protein interactions (Asano et al., 1992; Chapman et al., 1994) suggests one site for the physical association. However, based on hydrop- 
athy analysis, at least part of the leucine heptad repeat of GAT1 is localized within a putative transmembrane domain. Although some proteins have been shown to form protein-protein associations within transmembrane domains (McGinnes et al., 1993; Bernstein et al., 1995), our preliminary, unpublished data suggest that the syntaxin $1 \mathrm{~A}$ interaction site is not at the leucine repeat region directly. Rather, the GAT1 leucine mutant likely places GAT1 in a conformation such that an intracellular location on GAT1 is no longer accessible to syntaxin 1A.

Also to be determined is the mechanism by which syntaxin $1 \mathrm{~A}$ alters the number of functional transporter molecules. Interactions with syntaxin 1A may put plasma membrane transporters in an inactive conformation; alternatively, syntaxin 1A could control the trafficking of transporters to and from the plasma membrane. This latter hypothesis is supported by the evidence of regulated redistribution of expressed GAT1 transporters to and from subcellular compartments in oocytes (Corey et al., 1994b). However, in oocytes, both PKC and syntaxin 1A induce upregulation of GAT1 function by a net increase in surface transporter expression (Quick et al., 1997). This difference in the role of these two molecules in regulating GAT1 function in mammalian cells versus oocytes may be attributable to the targeting of GAT1 to different trafficking pathways. Upregulation of GAT1 function in oocytes may occur via a pathway similar to one that results in the PKC-induced exocytosis of cortical granules in oocytes (Bement and Capco, 1989; Scheuner and Holz, 1994).

PKC-mediated regulation of neurotransmitter transport is well described (for review, see Beckman and Quick, 1998). The present data suggest one mechanism for this effect; PKC regulates a network of protein interactions that influence transporter function. However, there may be other mechanisms through which PKC could exert its effects on transporters. Most neurotransmitter transporters contain multiple consensus sites for PKC phosphorylation, and direct phosphorylation of specific transporters has been shown (Casado et al., 1993; Conradt and Stoffel, 1997; Huff et al., 1997; Vaughan et al., 1997; Ramamoorthy et al., 1998). Removal of all consensus PKC phosphorylation sites on GAT1, including those in the cytoplasmic tails (Corey et al., 1994b), and of threonine 236 (present study; data not shown) failed to eliminate the PKC-mediated inhibition of GAT1, but such results do not eliminate PKC effects at nonconsensus sites; nor do these results eliminate multiple pathways for PKC-mediated transporter inhibition. However, the present data showing PKC regulation of GAT1 in neurons and not in glia, and only in the presence of components of the docking and fusion apparatus, argue for an indirect effect of PKC on GAT1 function. Another possibility for PKC regulation in neurons but not in glia is that the PKC-mediated effects are specific to the transporter encoded by GAT1. Although GAT1 is expressed in both hippocampal neurons and glia, it is possible that other GABA transporter isoforms predominate in astrocytes (e.g., GAT3; Ribak et al., 1996) and that they are not regulated by PKC.

Our data on modulation of endogenous glutamate transport lends support to the idea of multiple pathways for PKC-mediated regulation. In both neurons and glia, PMA induces an increase in glutamate transport that occurs in the presence of BONT/C1. This syntaxin 1A-independent increase in transport may be attributable to direct phosphorylation of the transporter by PKC (Casado et al., 1993), although we cannot eliminate PKC mediating its effects via protein-protein interactions that are independent of syntaxin 1A. In neurons, coapplication of BONT/C1 and PMA results in upregulation of transport that is greater than that seen in cells treated with PMA alone; that is, BONT/C1 eliminates a PKC-dependent decrease in glutamate transport. These data demonstrate a syntaxin 1A-dependent action of PKC on glutamate transport that is similar to that seen with GABA transport.

In summary, the present data show that syntaxin $1 \mathrm{~A}$ regulates transporter function and that PKC exerts its effects on neurotransmitter uptake by controlling the interaction between these two neuronal proteins. These data also imply the converse, namely, that the transporter could control the availability of syntaxin $1 \mathrm{~A}$ to interact with its other binding partners: calcium channels and components of the docking and fusion apparatus. If the availability of syntaxin $1 \mathrm{~A}$ is limiting, then the participation of syntaxin $1 \mathrm{~A}$ in vesicle release might preclude it from downregulating transporter function. Thus, transporter function will be positively correlated with neurotransmitter release; such a mechanism would provide one route by which neurons could exert greater control over transmitter-mediated synaptic signaling.

\section{REFERENCES}

Asano T, Takata K, Katagiri H, Tsukuda K, Lin J-L, Ishihara H, Inukai K, Hirano H, Yazaki Y, Oka Y (1992) Domains responsible for the differential targeting of glucose transporter isoforms. J Biol Chem 267:19636-19641.

Barbour B, Keller BU, Llano I, Marty A (1994) Prolonged presence of glutamate during excitatory synaptic transmission to cerebellar Purkinje cells. Neuron 12:1331-1343.

Beckman ML, Quick MW (1998) Neurotransmitter transporters: regulators of function and functional regulation. J Membr Biol, in press.

Bement WM, Capco DG (1989) Activators of protein kinase C trigger cortical granule exocytosis, cortical contraction, and cleavage furrow formation in Xenopus laevis oocytes and eggs. J Cell Biol 108:885-892.

Bennett MK, Calakos N, Scheller RH (1992) Syntaxin: a synaptic protein implicated in docking of synaptic vesicles at presynaptic active zones. Science 257:255-259.

Bennett MK, García-Arrarás JE, Elferink LA, Peterson K, Fleming AM, Hazuka CD, Scheller RH (1993) The syntaxin family of vesicular transport receptors. Cell 74:863-873.

Bernstein HB, Tucker SP, Kar SR, McPherson SA, McPherson DT, Dubay JW, Lebowitz J, Compans RW, Hunter E (1995) Oligomerization of the hydrophobic heptad repeat of gp41. J Virol 69:2745-2750.

Bezprozvanny I, Scheller RH, Tsien RW (1995) Functional impact of syntaxin on gating of N-type and Q-type calcium channels. Nature 378:623-626.

Blasi J, Chapman ER, Yamasaki S, Binz T, Niemann H, Jahn R (1993) Botulinum neurotoxin $\mathrm{C} 1$ blocks neurotransmitter release by means of cleaving HPC-1/syntaxin. EMBO J 12:4821-4828.

Casado M, Zafra F, Aragon C, Gimenez C (1991) Activation of highaffinity uptake of glutamate by phorbol esters in primary glial cell cultures. J Neurochem 57:1185-1190.

Casado M, Bendahan A, Zafra F, Danbolt NC, Arag-n C, Giménez C, Kanner BI (1993) Phosphorylation and modulation of brain glutamate transporters by protein kinase C. J Biol Chem 268:27313-27317.

Chapman ER, An S, Barton N, Jahn R (1994) SNAP-25, a t-snare which binds to both syntaxin and synaptobrevin via domains that may form coiled coils. J Biol Chem 269:27427-27432.

Clark JA, Amara SG (1993) Amino acid neurotransmitter transporters: structure, function, and molecular diversity. BioEssays 15:323-332.

Conradt M, Stoffel W (1997) Inhibition of the high-affinity brain glutamate transporter GLAST-1 via direct phosphorylation. J Neurochem 68:1244-1251.

Corey JL, Guastella J, Davidson N, Lester HA (1994a) GABA uptake and release by a mammalian cell line stably expressing a cloned rat brain GABA transporter. Mol Membr Biol 11:23-30.

Corey JL, Davidson N, Lester HA, Brecha N, Quick MW (1994b) Protein kinase $\mathrm{C}$ modulates the activity of cloned $\gamma$-aminobutyric acid transporter expressed in Xenopus oocytes via regulated subcellular redistribution of the transporter. J Biol Chem 269:14759-14767.

Davis KE, Straff DJ, Weinstein EA, Bannerman PG, Correale DM, Rothstein JD, Robinson MB (1998) Multiple signaling pathways regulate cell surface expression and activity of the excitatory amino acid 
carrier 1 subtype of Glu transporter in C6 glioma. J Neurosci 18:2475-2485.

Diamond JS, Jahr CE (1997) Transporters buffer synaptically released glutamate on a submillisecond time scale. J Neurosci 17:4672-4687.

Fujita Y, Sasaki T, Fukui K, Kotani H, Kimura T, Hata Y, Südhof TC, Scheller RH, Takai Y (1996) Phosphorylation of Munc-18/n-sec1/rbSec1 by protein kinase C. J Biol Chem 271:7265-7268.

Guastella J, Nelson N, Nelson H, Czyzyk L, Keynan S, Miedel MC, Davidson N, Lester HA, Kanner BI (1990) Cloning and expression of a rat brain GABA transporter. Science 249:1303-1306.

Hata Y, Slaughter CA, Südhof TC (1993) Synaptic vesicle fusion complex contains unc-18 homologue bound to syntaxin. Nature 366:347-351.

Hestrin S, Sah P, Nicoll RA (1990) Mechanisms generating the time course of dual component excitatory synaptic currents recorded in hippocampal slices. Neuron 5:247-253.

Huff RA, Vaughan RA, Kuhar MJ, Uhl GR (1997) Phorbol esters increase dopamine transporter phosphorylation and decrease transport Vmax. J Neurochem 68:225-232.

Isaacson JS, Solis JM, Nicoll RA (1993) Local and diffuse synaptic actions of GABA in the hippocampus. Neuron 10:165-175.

Kee Y, Lin RC, Hsu S-C, Scheller RH (1995) Distinct domains of syntaxin are required for synaptic vesicle fusion complex formation and dissociation. Neuron 14:991-998.

Kobayashi E, Nakano H, Morimoto M, Tamaoki T (1989) Calphostin C (UCN-1028C), a novel microbial compound, is a highly potent and specific inhibitor of protein kinase C. Biochem Biophys Res Commun 159:548-553.

Larsson OM, Falch E, Krogsgaard-Larsen P, Schousboe A (1988) Kinetic characterization of inhibition of gamma-aminobutyric acid uptake into cultured neurons and astrocytes by 4,4-diphenyl-3-butenyl derivatives of nipecotic acid and guvacine. J Neurochem 50:818-823.

Lester HA, Mager S, Quick MW, Corey JL (1994) Permeation properties of neurotransmitter transporters. Annu Rev Pharmacol Toxicol 34:219-249.

Mager S, Naeve J, Quick MW, Labarca C, Davidson N, Lester HA (1993) Steady states, charge movements, and rates for a cloned GABA transporter expressed in Xenopus oocytes. Neuron 10:177-188.

McGinnes L, Sergel T, Morrison T (1993) Mutations in the transmembrane domain of the HN protein of Newcastle disease virus affect the structure and activity of the protein. Virology 196:101-110.

Minelli A, Brecha NC, Karschin C, DeBiasi S, Conti F (1995) GAT-1, a high-affinity GABA plasma membrane transporter, is localized to neurons and astroglia in the cerebral cortex. J Neurosci 15:7734-7746.

Mochida S, Sheng ZH, Baker C, Kobayashi H, Catterall WA (1996) Inhibition of neurotransmission by peptides containing the synaptic protein interaction site of N-type $\mathrm{Ca}^{2+}$ channels. Neuron 17:781-788. Naren AP, Nelson DJ, Xie W, Jovov B, Pevsner J, Bennett MK, Benos
DJ, Quick MW, Kirk KL (1997) Regulation of CFTR chloride channels by syntaxin and Munc18 isoforms. Nature 390:302-305.

Pevsner J, Hsu S-C, Scheller RH (1994) n-Sec1: a neural-specific syntaxin-binding protein. Proc Natl Acad Sci USA 91:1445-1449.

Qian Y, Galli A, Ramamoorthy S, Risso S, DeFelice LJ, Blakely RD (1997) Protein kinase C activation regulates human serotonin transporters in HEK-293 cells via altered cell surface expression. J Neurosci 17:45-57.

Quick MW, Corey JL, Davidson N, Lester HA (1997) Second messengers, trafficking-related proteins, and amino acid residues that contribute to the functional regulation of the rat brain GABA transporter GAT1. J Neurosci 17:2967-2979.

Ramamoorthy S, Giovanetti E, Qian Y, Blakely RD (1998) Phosphorylation and regulation of antidepressant-sensitive serotonin transporters. J Biol Chem 273:2458-2466.

Ribak CE, Tong WMY, Brecha NC (1996) GABA plasma membrane transporters, GAT-1 and GAT-3, display different distributions in the rat hippocampus. J Comp Neurol 367:595-606.

Sarantis M, Ballerini L, Miller B, Silver RA, Edwards M, Attwell D (1993) Glutamate uptake from the synaptic cleft does not shape the decay of the non-NMDA component of the synaptic current. Neuron 11:541-549.

Scheuner D, Holz RW (1994) Evidence that the ability to respond to a calcium stimulus in exocytosis is determined by the secretory granule membrane: comparison of exocytosis of injected bovine chromaffin granule membranes and endogenous cortical granules in Xenopus laevis oocytes. Cell Mol Neurobiol 14:245-257.

Sheng Z-H, Rettig J, Takahashi M, Catterall WA (1994) Identification of a syntaxin-binding site on N-type calcium channels. Neuron 13:1303-1313.

Söllner T, Whiteheart SW, Brunner M, Erdjument-Bromage H, Geromanos S, Tempst P, Rothman JE (1993) SNAP receptors implicated in vesicle targeting and fusion. Nature 362:318-324.

Sonders MS, Amara SG (1996) Channels in transporters. Curr Opin Neurobiol 6:294-302.

Takayasu M, Suzuki Y, Shibuya M, Asano T, Kanamori M, Okada T, Kageyama N, Hidaka H (1986) The effects of HA compound calcium antagonists on delayed cerebral vasospasm in dogs. J Neurosurg 65:80-85.

Tong G, Jahr CE (1994) Block of glutamate transporters potentiates postsynaptic excitation. Neuron 13:1195-1203.

Vaughan RA, Huff RA, Uhl GR, Kuhar MJ (1997) Protein kinase $\mathrm{C}$-mediated phosphorylation and functional regulation of dopamine transporters in striatal synaptosomes. J Biol Chem 272:15541-15546.

Ye Z-C, Sontheimer H (1996) Cytokine modulation of glial glutamate uptake: a possible involvement of nitric oxide. NeuroReport $7: 2181-2185$. 